\title{
As narrativas na contemporaneidade: algumas características elementares e seus tipos de leitores
}

\author{
Contemporary narratives: some elementary characteristics and their related readers
}

Las narrativas en la contemporaneidad: algunas características elementales y sus tipos de lectores

\author{
Cleber Nelson Dalbosco 1 \\ Tania Mariza Kuchenbecker Rösing ${ }^{1} 1$ \\ ${ }^{1}$ Universidade de Passo Fundo, Passo Fundo, Rio Grande do Sul, Brasil.
}

$\diamond$

\begin{abstract}
RESUMO
Toda e qualquer narrativa tende a apresentar as marcas de seus respectivos suportes/mídias e da época em que foram criadas e veiculadas. Mas, para além dessa, que é a mais evidente e comum característica, pode-se notar a expressividade do contexto de assimilação por parte dos leitores, bem como a influência que os diferentes meios ocasionam na maneira de se criar e consumir narrativas. Portanto, busca-se aqui, através de referencial teórico interdisciplinar, compreender as mais perceptíveis mudanças nas narrativas contemporâneas, discutindo aspectos ligados ao universo da literatura, leitura, cinema, comportamento humano, design, comunicação e sociedade.
\end{abstract}

Palavras-chave: Narrativas contemporâneas. Fragmentação narrativa. Pessoas-tipográficas. Pessoas pós-tipográficas.

\begin{abstract}
Each and every narrative tends to expose marks of their respective media and of the time in which they were created and transmitted. But beyond that which is the most evident and common characteristic, it is possible to understand the expressiveness of the context of assimilation by the readers, as well as the influence that different media cause in the way of creating and consuming narratives. Therefore, it is sought here, through an interdisciplinary theoretical reference, to evidence the most noticeable changes in contemporary narratives, discussing related aspects to the universe of literature, reading, cinema, human behavior, design, communication, and society.
\end{abstract}

Keywords: Contemporary narratives. Narrative fragmentation. Typografic people. Post-typografic people.

\section{RESUMEN}

Cada narrativa tiende a presentar marcas de sus respectivos medios de comunicación y el momento en que fueron creados y vehiculados. Pero además de esto que es la característica más evidente y común, se puede notar la expresividad del contexto de asimilación por parte de los lectores, así como la influencia que los diferentes medios causan en la forma de crear y consumir narrativas. Por lo tanto, busca aquí, a través de un marco teórico interdisciplinario, comprender los cambios más perceptibles en las narrativas contemporáneas, discutiendo aspectos relacionados con el universo de la literatura, la lectura, el cine, el comportamiento humano, el diseño grafico, comunicación y sociedad.

Palabras clave: Narrativas contemporâneas. Fragmentación narrativa. Personas-tipográficas. Personas post-tipográficas. 


\section{Características elementares}

As narrativas, ou a maneira como as histórias são contadas, perpassam as lógicas de estruturação. A literatura expôs, ao longo da História, a classificação, por exemplo, quanto aos tipos narrativos, nos quais são contempladas categorias como romance, novela, conto, crônica, fábula, parábola, apólogo, anedota e lenda. Não é proposição de este artigo discutir delimitações conceituais de gênero, nem esmiuçar as características, potencialidades e limites de cada uma das nomenclaturas e categorizações. Entende-se que, embora importantes, tais acepções destoam do propósito central desse artigo, que consiste na compreensão das características essenciais das narrativas contemporâneas. É em uma acepção interdisciplinar, envolvendo definições advindas de considerações teóricas que perpassam questões de leitura, literatura, sociedade, comportamento humano, comunicação, design e tecnologias, que se busca evidenciar as relações das narrativas oriundas de diferentes suportes com os respectivos leitores.

Ao conceito de enredo, por exemplo, um dos elementos imprescindíveis para a compreensão da narrativa, segundo a proposição da literatura exposta por Massaud Moisés, tem-se: "Vocábulo de conotação algo incerta, não raro se emprega num sentido próximo ou equivalente a 'intriga', 'história', 'assunto', 'argumento', plot, 'trama', 'fábula"' (MOISÉS, 1982, p. 173, grifo do autor). Assim, nota-se a proximidade com o conceito de "intriga", que, em Carlos Reis e Ana Cristina Lopes, “[...] corresponde a um plano de organização macroestrutural do texto narrativo e caracteriza-se pela apresentação dos eventos segundo determinadas estratégias discursivas" (REIS; LOPES, 1988, p. 211-212).

Tal conceituação estabelece a noção distintiva do conceito de fábula, já que essa seria o ordenamento dos acontecimentos respeitando a cronologia, perpassando o favorecimento e a assimilação do conteúdo da narrativa. Por esta mesma razão, pode-se dizer que a fábula, enquanto gênero, evidencia uma moral da história, algo que, talvez em uma narrativa não linear, teria sua compreensão menos evidente. No conceito de intriga, estaria a valorização da forma, uma vez que a intriga seria, conforme exposto em Reis e Lopes, a "elaboração estética da fábula".

Ao elaborar esteticamente os elementos da fábula, a intriga provoca a "desfamiliarização", o estranhamento, chamando a atenção do leitor para a percepção de uma forma. Nesse processo de elaboração estética do material, assume especial relevo a questão da ordenação temporal: à linearidade de consecução das ações, na fábula, opõe-se muitas vezes a disposição não-linear dessas ações, no plano da intriga (antecipação, diferimento, começo in medias res, etc.; v. anacronia) (REIS; LOPES, 1988, p. 212).
A palavra que, possivelmente, traduz todo esse universo é a (re)elaboração. Esse mecanismo, se assim puder ser entendido, constitui um método de assimilar, incorporar, para depois construir desconstruindo o que anteriormente era comum, proposto ou feito de modo "convencional". O ato de reelaborar alguma coisa cria automaticamente sentidos diferentes. Por exemplo, a mudança de uma sequência ${ }^{1}$ de cenas em um filme, a disposição de como os fatos irão se conectar certamente alteram a percepção e podem contribuir para outros significados na percepção da obra, bem como influenciar a maneira de assimilação. Estar-se-á saindo de uma forma de apresentação para adentrar em outras. E isso não se opera unicamente no cinema e na literatura, mas em um amplo espectro, incluindo a relação com os receptores, algo que se depreende das considerações do historiador da cultura e da leitura, Roger Chartier, que expõe: “[...] os 'consumidores' são sempre produtores de significados e deslocam, estremecem ou subvertem as intenções dos criadores de obras e produtos culturais" (CHARTIER, 2014, p.36).

Em conceitos mais próximos à prática cinematográfica, por exemplo, a definição de enredo é comumente associada à noção de sequência, em que fatos acontecem na história envolvendo personagens e qualificando a motivação de suas ações. $\mathrm{O}$ enredo estaria dividido em duas tipificações: linear e alinear. No enredo linear, os acontecimentos e o desenvolvimento das ações das personagens são evidenciados de maneira cronológica, tentando preservar a lógica equilibrada entre antecedentes e consequências das ações.

No enredo não linear caberia a completa desconstrução da lógica formal dada pelo expor de "começo, meio e fim" cronológicos. A não linearidade é marcada pela evidência de saltos, retrospectivas e antecipações expostas em um fluxo de rupturas constantes em que ocorrem misturas frequentes entre fatos psicológicos com fatos temporais. A própria noção de diegese e metadiegese passa a ser intercalada, desrespeitando a cronologia em prol da valorização da trama, isto é, o conteúdo passa a ser subjugado em relação à forma.

Trama, portanto, pressupõe a lógica da escaleta ${ }^{2}$, isto é, de encadeamento, em que o mais importante não é propriamente o conteúdo e a lógica de casualidade

\footnotetext{
Na acepção explicativa de Syd Field, "uma série de cenas ligadas, ou conectadas, por uma única ideia com início, meio e fim definidos. É um microcosmo do roteiro, do mesmo jeito que uma simples célula contém as propriedades básicas do universo. [...] A sequência é um todo, uma unidade, um bloco de ação dramática, completa em si mesma" (FIELD, 2001, p. 88).

2 De acordo com Maciel "a escaleta é a tarefa específica de roteirização, pois é a divisão da história nas cenas que melhor a exibirão ao público. Ao escaletar, o roteirista decide que cenas ele vai mostrar, que cenas vai esconder em elipses eficientes, e como vai encadeá-las" (MACIEL, 2003 p. 26).
} 
cronológica, mas o estilo, a maneira de se contar a história, através da escolha e indicação de cenários e temporalidades significativas para sua efetiva percepção. Em outras palavras, fragmentos de partes e temporalidades da história são contrapostos em prol de despertar a angústia perceptiva, tentando cativar o leitor/espectador fazendo com que ele tente adivinhar o desenlace da narrativa. Tal qual um quebra-cabeças, ao leitor/espectador compete decifrar e completar a "imagem", baseando-se nas peças que lhe foram disponibilizadas, na ordem em que foram disponibilizadas. Nesse processo de interpretação, apela-se inclusive para a bagagem cultural do leitor/ espectador, nas suas vivências e leituras depositadas em sua "biblioteca mental".

Esse tipo de enredo - ou intriga, segundo a classificação comumente apresentada pelos estudos literários -, em que os saltos temporais são recorrentes, pode também ser nomenclaturado como "fragmentado" ou "pós-moderno"3. Aqui, porém, deve-se atentar para algo que, comumente, passa despercebido. A narrativa linear, assim como a narrativa alinear, sempre existiu.

Ao narrar qualquer acontecimento - uma conquista ou um problema - para alguém, normalmente as pessoas não partem contando desde o início do dia, acabam objetivando por contar o fato em si, aquilo que aconteceu, onde e quando. Mesmo que sejam lineares os relatos do evento em si, raramente são mencionados os antecedentes, as motivações e as ideias correlatas, bem como são negligenciados pequenos detalhes, a fim de não cansar o ouvinte. Nessas situações, os seres humanos são fragmentários. Diferentemente do que acontece com a vida de qualquer sujeito vivente, que sucede um processo gradual e histórico de crescimento e desenvolvimento para, um dia, terminar. Os fatos do cotidiano humano e pessoal são contados de modo alinear. A existência humana é linear. A consciência e o decorrente ato de (re)lembrar alguma coisa parecem ocorrer em "saltos", não lineares, portanto. Logo, pode-se dizer que, a "pósmodernidade", talvez tenha acentuado a percepção sobre o efeito de fragmentação, mas, em absoluto, não o criou. Afinal, os termos - já "clássicos" - fábula e intriga se referiam, quanto à forma, aos modos da narrativa linear e não linear, respectivamente.

\footnotetext{
3 De acordo com Fredric Jameson, que mais atualmente diferencia "pós-modernismo" de "pós-modernidade", o primeiro seria um estilo e o segundo, segundo suas palavras, "uma estrutura". Portanto, a "pós-modernidade", sendo uma estrutura - ao contrário do estilo irá perdurar por muito tempo ainda, sobretudo, no contemporâneo mundo globalizado. Porém, convém aqui destacar, no entendimento de Jameson, a definição de que "os dois traços da pós-modernidade [...] a transformação da realidade em imagens, a fragmentação do tempo em uma série de presentes perpétuos" (JAMESON, 1985, p. 16-26).
}

\section{A modernidade e o "pós"}

Interessante notar que a pós-modernidade secreta em si o conceito de modernidade, imbuindo uma lógica de acúmulo conceitual, em que, para se entender a "pós", necessário é que se compreenda o "moderno". Moderno infere na lógica de referência à "idade moderna”, em que o surgimento do capitalismo trouxe as ditas "revoluções burguesas" - sendo a mais famosa delas a de 1789, data da Revolução Francesa -, que ascendem em virtude da decadência do regime feudal e seu sistema estamental de pouca, ou quase inexistente, mobilidade social. Porém, nas artes, o termo "modernismo" consistiu numa ideia de rompimento com os períodos anteriores.

\begin{abstract}
Quando as pessoas falam sobre "Arte Moderna", geralmente pensam em um tipo de arte que rompeu por completo com as tradições do passado e tenta fazer coisas com que nenhum artista sonhou antes. [...] Aqueles que lamentam a quebra da tradição teriam de voltar para antes da Revolução Francesa de 1789, e poucos julgariam isso possível. Foi nesse momento [início do século XX], como sabemos, que os artistas começaram a se preocupar com definições de estilo e a experimentar e lançar algum novo "ismo" como grito de guerra. [...] $\mathrm{O}$ futuro pertencia àqueles que decidissem começar de novo e livrar-se da preocupação com estilo ou adornos, fossem estes novos ou velhos (GOMBRICH, 2013, p. 429).
\end{abstract}

O modernismo surge com o propagar de uma ideologia de ver, sentir, viver e estar no mundo. Ao mesmo tempo que quer romper com o que existia antes, zombando e escarnecendo, configura-se sob a égide de manifestos, influenciando e criando novos posicionamentos de como a arte deveria ser. Apelando para a "funcionalidade" e para a "simplificação", desvencilhando-se de "adornos" considerados desnecessários, infundiu uma lógica de rompimento e, ao mesmo tempo, expansão, possibilitada pelo panorama das transformações técnicas e industriais. Por essa razão, o design e as demais disciplinas resultantes dos estudos da aplicabilidade industrial tornam-se referenciais a partir de então. Assim, tudo que passou a apresentar um apelo diferenciado em sua forma, isto é, enfatizou o design, torna-se possível de ser entendido como "moderno". Contudo, além disso, o modernismo, assim como outros "ismos" que o sucederam, abriu portas para a arte enquanto manifesto político em escala global, graças aos sistemas industriais mais ou menos padronizados e a comunicação de massa.

A raiz do modernismo, de certa forma, reside no surgimento da "era moderna", em que o advento da burguesia ascendente, a criação de cidades burguesas, a possível mobilidade das classes sociais, a criação de 
novos negócios, técnicas, estratégias e tecnologias - entre elas a prensa tipográfica de Gutenberg - possibilitaram o aparecimento da profusão não apenas dos livros, dos jornais, dos veículos de imprensa, mas, sobretudo, a disseminação do conhecimento, antes restrito ao clero e aos nobres. Com a disseminação do conhecimento, inclusive a propagação de ideias "revolucionárias" ${ }^{4}$ " se tornou mais fácil. O mercado expande-se gradualmente e a literatura se apresenta também como recurso de entretenimento disponível, vindo a ser gradual e amplamente difundida.

Assim, após a criação da prensa e a imprensa, um novo sistema social e econômico começa a despontar, uma nova maneira de se contar histórias começa a ganhar forma. Desse modo, o romance burguês, relativamente fácil de ser assimilado - diferentemente da poesia, que requer, muitas vezes, o conhecimento de referências históricas, habilidade de interpretação polissêmica e imaginação sonora e rítmica das palavras -, a partir do século XIX, configura-se na espécie literária mais consumida. É oportuno considerar a argumentação de Ian Watt (2010), mesmo que contextualizando o século XVIII, pois dela depreende-se a relação de que o romance inaugura um modo distinto de consumo não apenas de literatura, mas de narrativas, de sensorialidades latentes e potenciais, visto que

[...] o romance constituía a principal atração e sem dúvida foi o gênero que mais contribuiu para ampliar o público leitor de ficção ao longo do século. Foi também a forma literária que suscitou o maior volume de comentários contemporâneos sobre a extensão da literatura às classes inferiores (WATT, 2010, p.45).

Não menos oportuno é o reportar de Watt para os comentários advindos da crítica ao fato da disseminação do romance entre as classes sociais menos abastadas. "Dizia-se que essas 'lojinhas de literatura' corrompiam a mente de escolares, lavradores, 'criadas da melhor espécie', e até mesmo de 'todo açougueiro e padeiro, remendão e latoeiro nos três reinos" (WATT, 2010, p. 45).

Há de se considerar que a ascensão do romance não deixa de ser a resultante de um expansivo processo de consumo e assimilação de narrativas escritas. Nisso está presente a lógica de entretenimento. Ao mesmo tempo, fazem-se evidentes rupturas que se apresentam ao universo simbólico e imaginário também das pessoas simples, não estando, por fim, restritas apenas aos nobres. São as ideias expostas nos romances - em que reside

\footnotetext{
4 Ver: EISENSTEIN, Elisabeth L. The Unacknowledged Revolution. In: EISENSTEIN, Elisabeth L. The Printing Press as an Agent of Change: Communications and Cultural Transformations in Early-Modern Europe. Cambridge: Cambridge University Press, 1997. p. 3-42. 794 p.
}

a força impulsiva e potencial de questionamento, de rompimento com a materialidade imediata do dia a dia de pessoas que desempenham funções serviçais - capazes de expor descontentamentos, tristezas e injustiças.

Nos romances, os sentimentos vão sendo evidenciados e comunicados, gerando a potencial identificação por parte dos leitores, que tendem a exercer influência sobre o agir social. São as revoluções, os acontecimentos representativos do agir social que não deixam de estar relacionados ao propagar dos sentimentos de descontentamento e revolta. A literatura, a narrativa, em suas mais diversas materialidades e apresentações, jamais deixa de corporificar e (re)apresentar mundos, hipóteses e soluções. Afinal, qualquer revolução tenta se justificar como "solução" aos problemas existentes numa sociedade.

Enaltecendo as possibilidades "revolucionárias", exibidas no transcorrer da Idade Moderna, correntes filosóficas irão desse substrato/sentimento "revolucionário", principiado no decorrer deste período histórico, retirar sua força. Nas décadas iniciais do século $\mathrm{XX}$, tais ideias ganham espaço na forma de um movimento. $\mathrm{O}$ aparecimento do modernismo como corrente de influência, de acordo com psicólogo canadense Steven Pinker (2004), gera impacto nas artes como um todo, permeando inclusive o design (simplificação das formas e apelo à funcionalidade); a arquitetura (prédios em formas de caixas, também chamados de "máquinas de viver"); a música (atonalidade, serialidade, dissonâncias e dodecafonismo). Quanto à literatura no contexto do modernismo, em específico, Pinker observa:

[...] a narração onisciente, as tramas estruturadas, a introdução ordenada de personagens e a compreensão geral da leitura foram substituídas por um fluxo de consciência, eventos apresentados fora de ordem, personagens e sequências causais desconcertantes, narração subjetiva e desarticulada e prosa difícil (PINKER, 2004, p. 554).

Não só a narrativa, mas também a cultura e a maneira de disseminá-la são potencializadas enquanto dependentes de processos de comunicação midiática. Desse modo, no transcorrer do século XX, inclusive a narrativa cinematográfica apresenta mudanças. Essas mudanças são também denominadas "narrativas pós-modernas", em que as histórias em "quebra-cabeças" ganham expressão acentuada, oferecendo constantemente perguntas ao invés de prontas respostas. É nesse considerar que o professor e cineasta Carlos Gerbase (2003) interpreta o pós-modernismo, considerando, para tal, proposições da crítica literária canadense Linda Hutcheon. Nas palavras de Gerbase: 
Para Hutcheon, o paradigma pós-modernista é, antes de mais nada uma saída para o formalismo exagerado do modernismo, que tinha uma série de certezas sobre o mundo e alguns projetos definidos para a sua evolução. Os projetos, como sabemos, não deram certo. O pós-modernismo, nesse vácuo, pretende fazer mais perguntas e dar menos respostas, além de permanecer sempre desconfiado sobre qualquer certeza - histórica ou estética (GERBASE, 2003, p. 161).

O (re)inaugurar dessa forma de contar histórias afinal, a intriga era a reelaboração da fábula, como visto em Reis (1988) - causa impacto na quase totalidade dos produtos voltados à ficção. Também tem seu reflexo em um diversificado número de produtos narrativos, como o cinema; games que requerem conhecimento antecipado sobre o universo dos personagens e seus contextos psicológicos e demográficos; a navegação na internet e, inclusive, novamente, o livro, que incorpora a influência através de termos, temáticas ou caminhos discursivonarrativos.

\section{Invasões tecnológicas e seus leitores}

Assim, nota-se que os estudos literários também consideram as características e possibilidaldes das diferentes mídias. Helena Bonito Pereira (2011) não destoa de tal acepção, apontando para a influência de que a cultura de massa e, portanto, dos meios, se desenrola nos processos criativos da literatura. Assim, na literatura contemporânea, ocorre uma miríade de aproximações metalinguísticas e referenciais, em que o texto sofre mudanças não apenas quanto ao seu processo de escrita, mas também quanto aos temas e à transversalidade de elementos.

Efeito da invasão tecnológica, a contaminação por outras mídias complica um pouco, mas não inviabiliza a criação literária. Pode até ter contribuído para a intensificação de um recurso narrativo amplamente empregado nas obras contemporâneas, o da fragmentação ou desintegração formal assumida como princípio artístico (PEREIRA, 2011, p. 41-42).

A fragmentação narrativa, mais propriamente do enredo, ganha profusão em ambientes que já não preservam a noção linear desde seu nascedouro. Essa fragmentação narrativa passa a estar presente nas cidades (através da mobilidade urbana, no "dobrar à esquina" ao acaso, seja por algum interesse imediato, seja por alguma ameaça, seja pelo simples trajeto do ônibus); na televisão (com seus indefectíveis intervalos comerciais, vinhetas e chamadas de programação que interrompem constantemente o fluir das telenovelas, filmes e programas); na internet (com sua navegabilidade, seus hiperlinks e sua condição hipermídia ${ }^{5}$ ). Nesses ambientes, tanto reais quanto virtuais, enredo torna-se trama e a importância recai na interpretação, na maneira de "soldar os eventos", sejam eles pré-definidos, sejam frutos do acaso. E quem efetua a interpretação, vale salientar, é o leitor/espectador.

Lucia Santaella (2007), considerando a leitura e seus contextos de assimilação, expõe uma classificação dos leitores desde o início da profusão dos textos impressos - o inaugurar da prensa tipográfica de Gutenberg até os tempos atuais -, em que as infovias e seus "nexos eletrônicos" passam a intervir não apenas na percepção do texto enquanto recurso que demanda a atenção dos olhos humanos, mas que condiciona e causa impactos inclusive na mobilidade do corpo humano. Como proposto por Santaella, são evidentes três tipos de leitores: o contemplativo, o movente e o imersivo. "O primeiro [...] é o leitor contemplativo, meditativo da idade pré-industrial, o leitor da era do livro impresso e da imagem expositiva, fixa. Esse tipo de leitor nasce do Renascimento e perdura hegemonicamente até meados do século XIX." (SANTAELLA, 2007, p. 19). Necessário atentar que esse padrão de comportamento de leitura, o leitor contemplativo, permanece ainda hoje e, ao que parece, não será extinto tão rapidamente. Aliás, pode-se inferir que dificilmente deixarão de existir tais leitores.

Um segundo modelo de leitor, proposto por Santaella (2007), já denota o indício do hibridismo, da mistura, da relação e necessidade de conexões a serem estabelecidas no propósito da interpretação e na tentativa de ordenamento lógico. Esse leitor prescinde de caminhos, muitas vezes físicos, onde transita e coabita com a casualidade e com a possível interrupção da atenção, ao mesmo tempo que pode negar o entorno e mergulhar na narrativa enquanto transita pelo seu roteiro diário de deslocamento.

[...] é o leitor do mundo em movimento, dinâmico, mundo híbrido, de misturas sígnicas, um leitor que é filho da Revolução Industrial e do aparecimento dos grandes centros urbanos: o homem na multidão. Esse leitor, que nasce com a explosão do jornal e com o universo reprodutivo da fotografia e do cinema, atravessa não só a era industrial, mas mantém suas características básicas quando se dá o advento da revolução eletrônica, era do apogeu da televisão (SANTAELLA, 2007, p. 19).

\footnotetext{
5 No conceituar de Santaella, "hipermídia significa, sobretudo, enorme concentração de informação. Ela pode consistir de centenas e mesmo milhares de nós, com uma densa rede de nexos. A grande flexibilidade do ato de ler uma hipermídia, leitura em trânsito, funciona, contudo, como uma faca de dois gumes. Ela pode se transformar em desorientação se o receptor não for capaz de formar um mapa cognitivo, mapeamento mental do desenho estrutural de um documento" (SANTAELLA, 2007, p. 50).
} 
Segundo a autora, "o terceiro tipo de leitor é aquele que começa a emergir nos novos espaços incorpóreos da virtualidade" (SANTAELLA, 2007, p. 19). Notase, portanto, que cada principiar tecnológico, cada inauguração de processo de disseminação de conhecimento e pensamento trazem alterações não apenas ao modo de leitura, mas, também, ao modo de comunicar ideias e sentimentos, bem como de contar histórias. Isso porque representar o mundo, as angústias e as sensações físicas e psicológicas que caracterizam a existência humana é algo constante e necessário; contudo, igualmente mutável.

Nisso se revela a dimensão de que narrativa não é apenas o desenvolver de um enredo, através de recursos linguísticos, retóricos, estáticos ou dinâmicos, lineares ou fragmentados. A ânsia por comunicar é típica do ser humano, que, representando a si mesmo como sujeito, acaba, por vezes, representando os sentimentos de toda uma época e de um grupo de pessoas, mais ou menos iguais em angústias, inquietações, vontades, sonhos e perspectivas. Eis o motivo pelo qual algumas obras passam a significar e representar "toda uma geração".

Ler e consumir, ao mesmo tempo, escrita, sons e imagens certamente são a caracterização contemporânea das pessoas que utilizam os mais diferenciados meios de comunicação. A profusão de elementos, em uma sensação de ubiquidade ${ }^{6}$ permanente, em que a interação e a mobilidade dos dispositivos tornam possível o inaugurar, elaborar e comunicar pensamentos a cada instante, "compartilhando" com seus afetos e desafetos tudo o que sente ou vê, não deixa de ser o sine qua non da contemporaneidade. Há nisso a evidência de um sistema comunicativo que tem no ato da leitura sua demanda permanente, visto que ler também exige predisposição para interpretar, assimilar e agir.

$\mathrm{O}$ apelo aos mais diferentes suportes e/ou mídias configura aquilo que pode ser denominado um sistema de multiplataformas. Igualmente, formam-se processos de multitrocas, multileituras, e multiletramentos ${ }^{7}$. Embora as mais diversas terminologias possam ser empregadas para designar o conjunto de possibilidades e práticas de quem lê diferentes gêneros de textos, incluindo aí textos expostos em imagens estáticas e em movimento, convém se atentar para a constante em todo processo de leitura: a capacidade de interpretação.

É preponderante atentar para o fato de que as possibilidades de interpretação, requeridas ao leitor, sofrem influências dos suportes, ou seja, dos meios. Há de se considerar, também, que alguns desses meios exigem certas habilidades, indo desde uma leitura

\footnotetext{
6 Ver: SANTAELLA, Lucia. Comunicação ubíqua: repercussões na cultura e na educação. São Paulo: Paulus, 2013. 376 p.

7 Ver: ROJO, Roxane (Org.). Escola conectada: os multiletramentos e as TICs. São Paulo: Parábola, 2013. 278 p.
}

mais rápida até a capacidade de reagir e interagir quase que instintiva e permanentemente. Termos como multimodalidade ${ }^{8}$, contudo, valorizam os estudos dos suportes enquanto recurso didático, ou melhor, atentam para a necessidade de letrar-se para o uso e leitura nos múltiplos suportes. Mas tal conceito parece se assentar na lógica de empoderamento dos meios e das tecnologias da informação e comunicação, e não na valorização da preocupação com o conteúdo e sua interpretação. Como se o pressuposto domínio no uso das ferramentas gerasse per se o domínio sobre o conteúdo.

É importante frisar que o suporte pode adicionar, interpor ou remover facilmente o conteúdo e, consequentemente, gerar significados; contudo, não pode ser visto como o principal de uma mensagem. A mensagem está condicionada ao seu receptor, que tende a articular sua bagagem cultural, sua vivência e conhecimento prévio para interpretá-la ${ }^{9}$, seja ela escrita em papel, narrada pela voz de um locutor de rádio, seja no grafismo de frases em para-choques de caminhão.

Não se nega que os mais distintos suportes exerçam influência sobre os textos; no entanto, pode-se afirmar que as consequências são acentuadamente comportamentais e residem muito mais no modo de se relacionar com o conteúdo de uma mensagem do que com a forma. É inegável que, muitas vezes, as formas são tomadas como conteúdo principal, talvez porque acabam sendo mais perceptíveis e evidentes em curto prazo, pois se apresentam prontamente com seus "novos" recursos e métodos, requerendo "novas" habilidades.

Com efeito de explicação do argumento que aqui se objetiva expor, apela-se a seguinte metáfora: uma melodia, por exemplo, não deixa de ser uma melodia porque é assoviada, ou porque foi executada e gravada por uma orquestra. Valorizar em demasia os suportes, entendendo-os como a "novidade" permanente, é se deixar levar pela lógica de impacto visual e sonoro da orquestra e passar a esmiuçar o funcionamento e método de ensino de cada instrumento, seus recursos, vozes, timbres e potencialidades rítmicas, correndo o risco de nisso se perder por estar demasiado deslocado do principal. Caberia questionar: qual o sentido disso tudo se o principal, a melodia, não for percebida, assimilada e (re)lembrada pelo público?

Não se nega aqui a particularidade e potencialidade dos suportes, dos meios como recursos que adicionam significados e potencializam a disseminação de uma mensagem. É correto ter-se que os meios se influenciam

\footnotetext{
8 Ver: LEMKE, Jay. Multimodality, identity, and time. Disponível em: http://static1.1.sqspcdn.com/static/f/694454/12422458/1306510897553/ Multimodality-identity-time-2009.pdf?token=26heZoh6DjCDiX8zEZP 6Z12gEDA\%3D. Acesso em: 9 out. 2018.

9 Ver: LIBERATO, Yara; FULGÊNCIO, Lúcia. É possível facilitar a leitura: um guia para escrever claro. São Paulo: Contexto, 2007. 175 p.
} 
mutuamente o tempo todo e, assim, acabam adicionando, suprimindo e renovando a utilização das diferentes estéticas e linguagens. Uma possibilidade de ilustrar a influência que um suporte exerce sobre o outro está naquilo que o designer Philip Baxter Meggs salienta:

A mídia cinética tem invadido a página impressa, mudando o jeito com que a imagem e a tipografia são utilizadas. Contraditoriamente, o novo design gráfico [o autor refere-se ao contexto dos anos noventa do século $\mathrm{XX}]$ é um sintoma da lacuna existente entre uma vasta geração TIPOGRÁFICA e pós-TIPOGRÁFICA de pessoas (CARSON; MEGGS, 1999, p. 69, grifo dos autores, tradução nossa $)^{10}$.

Percebe-se nessa lógica que a imagem em movimento contaminou a imagem estática. A televisão e o cinema contaminam a estética, o modo de percepção e de arranjo dos elementos da página impressa. Uma forma contamina a outra, condicionando o conteúdo. Tais situações autorizam afirmar que os meios mudam, condicionam a percepção das mensagens - naquilo que Marshal McLuhan amplamente profetizou que "o meio é a mensagem ${ }^{11 " ~-, ~ a l t e r a n d o ~ n a ̃ o ~ a p e n a s ~ o ~ f o r m a t o ~ d a s ~}$ mensagens, mas afetando a maneira como são percebidas e, de tão percebidas, as formas é que passam a ser a "mensagem".

Nesse sentido, a contextualização dada por Meggs traduz o universo de transformações que um meio como a televisão, enquanto "mídia cinética" como ele define, causou na maneira de se ler, visto que haveria dois tipos de "pessoas", sendo as do primeiro tipo (grifos do autor): "PESSOAS TIPOGRÁFICAS: aquelas que desenvolveram suas habilidades primordiais de comunicação através do contato com a mídia impressa e, posteriormente, assimilaram a mídia eletrônica ${ }^{12}$ (CARSON; MEGGS, 1999, p. 69, tradução nossa).” Em contraposição, segue o autor caracterizando as "PESSOAS PÓS-TIPOGRÁFICAS: aquelas que desenvolveram suas habilidades primordiais de comunicação através do contato com a televisão e os videogames, e, posteriormente,

\footnotetext{
10 Do original: Kinetic media has invaded the printed page, changing the way, type and image are used togheter. Controversy about new graphic design is one symptom of a vast generation gap between TYPOGRAPHIC people and post-TYPOGRAPHIC people.

11 Algo interessante de se destacar é a explicação de Eric McLuhan (2011, p. 124) sobre o título do livro de seu pai: "O título deveria ser The medium is the Message [O meio é a mensagem] mas o compositor havia errado. Quando McLuhan viu o erro, exclamou 'Deixa assim! É ótimo, acertou na mosca!' Agora temos quatro possíveis leituras para o título, e todas precisas: 'message' (mensagem) e 'mess age' (era da bagunça); 'massage' (massagem) e 'mass age' (era da massa)." Ver: MCLUHAN, Marshall; FIORE, Quentin. O meio é a massagem: um inventário de efeitos. Tradução Julio Silveira. Rio de Janeiro: Imã Editorial, 2011. $128 \mathrm{p}$

12 Do original: TYPOGRAPHIC PEOPLE: Those who developed their early communication skills from print media, and then learned electronic media.
}

aprenderam a ler ${ }^{13} "$ (CARSON; MEGGS, 1999, p.69, tradução nossa).

Nota-se aí a influência que um suporte como a televisão, por exemplo, causou não sobre a mensagem propriamente, mas sobre a maneira de apresentá-la, influenciando a mídia impressa na maneira de agrupar recursos de informações, como tipos/fontes gráficas e imagens, bem como expondo às pessoas ainda não alfabetizadas uma relação de consumo de imagensmensagens diferente daquela advinda de pessoas alfabetizadas antes do advento da tecnologia referida.

Assim, a inserção das pessoas na lógica e no consumo dos aparatos e suportes midiáticos influenciou e, em certa medida, condicionou as habilidades de comunicação/ alfabetização. Nas "pessoas tipográficas", as habilidades desenvolviam-se à medida com que elas cresciam e aprendiam a ler com os meios impressos. Em um sentido inverso, "pessoas pós-tipográficas" desenvolveram sua alfabetização após terem crescido assistindo televisão e jogando videogames. A leitura nessas últimas, pode-se dizer, foi condicionada de maneira diferente, bem como a percepção, as habilidades e o desenvolvimento de todo processo de assimilação de conteúdos, afetando também, a maneira dessas pessoas agirem, criarem e se expressarem.

Se é possível, ainda retomando o exposto por Meggs, assumir que há um gap - isto é, uma "lacuna" - entre as "pessoas tipográficas" e "pessoas pós-tipográficas", causando possíveis desentendimentos, não quer dizer que pessoas que aprenderam a interpretar mensagens antes do advento dos meios de comunicação que expõem imagens em movimento sejam incapazes de interpretálas. Talvez nisso haja descompasso pela diferença e tolerância, bem como certa dificuldade, resistência e, sobretudo, familiaridade em lidar com essa maneira de apresentação. Nisso reside o gap, esse descompasso, essa "lacuna", na assimilação do que está sendo dito ou exposto. Isso é, e sempre será, uma constante no relacionamento entre as diversas gerações e os suportes midiáticos contemporâneos.

Há de se considerar que existem também "lacunas" no modo como a lógica da informação, da comunicação e, consequentemente, da narrativa, pode se apresentar. As deficiências de interpretação não são provenientes unicamente da incapacidade de lidar com o conteúdo proposto, mas, talvez, também tenham a ver com possíveis resistências de diferentes gerações em relação à forma e ao modo como aquilo chega até elas. Deve-se, porém, ter claro que nem todas as maneiras e modos de apresentação de um conteúdo agradam e comunicam da mesma maneira aos diferentes públicos.

\footnotetext{
${ }^{13}$ Do original: POST-TYPOGRAPHIC PEOPLE: Those who developed their early communication skills from television and video games, and then learned to read.
} 
A familiaridade com a forma de apresentação reconhecível, ou seja, com determinado gênero, possibilita antever percursos e poupar tempo, uma vez que a profusão de inovações nas formas de apresentação de conteúdo tem mudado cada vez mais. Em contexto diferente do contemporâneo, o psicólogo Jerome Bruner já atentava para os efeitos da narrativa, independentemente do condicionamento dos gêneros, pois

[...] pode-se ler uma história em infindáveis modos diferentes. [...] Os modos alternados de leitura podem lutar um com o outro, casar um com o outro, zombar um do outro na mente do leitor. Há alguma coisa na narrativa, alguma coisa no enredo que desencadeia esse "conflito de gênero" nos leitores (BRUNER, 1997, p. 7).

É, portanto, na narrativa, mais enfaticamente no conteúdo, no enredo, que reside a força das histórias. A expressividade desse conteúdo, que ora vigora em páginas estáticas impressas, ora no recurso da imagem em movimento, em uma profusão quase interminável de efeitos intersemióticos, não é o principal a fazer de uma narrativa uma narrativa. É a representatividade, a capacidade de abarcar o imaginário e significar e, conduzir a experiência das pessoas que tomam contato com as histórias que fazem com que algo sobreviva e tenha valor cultural. Uma vez na cultura, sendo vista e revista, visitada e revisitada, uma narrativa elabora significações e importâncias atemporais, em que os suportes - sempre temporais - são coadjuvantes.

Os suportes, isto é, as mídias, bem como os gêneros modalizados no contexto de cada uma delas, embora imprimam significados, sendo capazes de impactar, não são capazes de substituir a importância que somente o valor existencial de uma narrativa que se produz e reproduz é capaz de gerar. Talvez seja impossível capacitar e letrar todas as pessoas em todos os gêneros, dada essa vertiginosa e constante mudança e disponibilidade de mídias.

Contudo, é possível estimular a consciência sobre a importância que as diferentes formas de leitura, sobretudo a leitura contemplativa, exercem como recurso capaz de amplificar a percepção e a sensibilidade. A narrativa não está dissociada disso tudo, pois é ela, antes de qualquer coisa, que faz apelo à atenção, à necessidade de estabelecer relações de causa e efeito, sempre exigindo a interação e imersão mental do receptor. É nisso que reside sua força; é por isso que deve ser defendida não como um mero recurso, mas quase como um valor inalienável da existência humana.

\section{Referências}

BRUNER, Jerome. Enfocando o literário. In: BRUNER, Jerome. Realidade mental, mundos possíveis. Tradução Marcos A. G. Domingues. Porto Alegre: Artes Médicas, 1997. p.3-11.

CARSON, David; MEGGS, Philip B. Fotografiks: an equilibrium between photography and design through graphic expression that evolves from content. London: Laurence King Publishing, 1999. 190p.

FIELD, Syd. A sequência. In: FIELD, Syd. Manual do roteiro: os fundamentos do texto cinematográfico. Tradução Álvaro Ramos. Rio de Janeiro: Objetiva, 2001. p. 86-100.

CHARTIER, Roger. A leitura como prática cultural. Entrevista com Roger Chartier. Revista Observatório Itaú Cultural, São Paulo, n. 17, p. 18-39, ago./dez. 2014. Disponível em: http:// d3nv1jy4u7zmsc.cloudfront.net/wp-content/uploads/2014/07/ OBS17 BOOK-PDF-final.pdf. Acesso em: 6 out. 2018. https://doi.org/10.18411/d-2016-154

GOMBRICH, Ernst Hans. Arte experimental: a primeira metade do século XX. In: GOMBRICH, Ernst Hans. A história da arte. Tradução Cristiana de Assis Serra. Rio de Janeiro: LTC, 2013. p.428-463. https://doi. org/10.11606/d.31.2018.tde-01032018-113045

EISENSTEIN, Elisabeth L. The Unacknowledged Revolution. In: EISENSTEIN, Elisabeth L. The Printing Press as an Agent of Change: Communications and Cultural Transformations in Early-Modern Europe. Cambridge and New York: Cambridge University Press, 1997. p.3-42. https://doi. org/10.2307/2861164

JAMESON, Fredric. Pós-modernidade e sociedade de consumo. Novos Estudos Cebrap, São Paulo, n. 12, p. 16-26, jun. 1985. Disponível em: https://edisciplinas.usp. br/pluginfile.php/2918778/mod_resource/content/1/516_13 base JAMESON \%20pos\%20-modernidade $\% 20 \mathrm{e} \% 20$ sociedade $\% 20 \mathrm{de} \%$ 20consumo_novos $\% 20$ estudos.pdf. Acesso em: 19 set. 2018. https://doi.org/10.1590/s010133002008000100003

LEMKE, Jay. Multimodality, identity, and time, p. 455-479, 2017. Disponível em: http://static1.1.sqspcdn.com/ static/f/694454/12422458/1306510897553/Multimodalityidentity-time-2009.pdf?token=26heZoh6DjCDiX8z EZP6Z12gEDA\%3D. Acesso em: 09 out. 2018.

LIBERATO, Yara; FULGÊNCIO, Lúcia. É possível facilitar a leitura: um guia para escrever claro. São Paulo: Contexto, 2007. $175 \mathrm{p}$.

MACIEL, Luiz Carlos. O roteiro. In: MACIEL, Luiz Carlos. $O$ poder do climax: fundamentos do roteiro de cinema e TV. Rio de Janeiro: Record, 2003. p. 15-31. https://doi. org/10.11606/d.27.2011.tde-10062013-111213

MCLUHAN, Marshall; FIORE, Quentin. O meio é a massagem: um inventário de efeitos. Tradução Julio Silveira. Rio de Janeiro: Imã Editorial, 2011. 128 p. 
MOISÉS, Massaud. Dicionário de termos literários. São Paulo: Cultrix, 1982. 520p.

PEREIRA, Helena Bonito. Breves apontamentos para a história literária brasileira. In: PEREIRA, Helena Bonito (org.). Novas leituras da ficção brasileira no século XXI. São Paulo: Ed. Mackenzie, 2011. p. 31-49. 390p. https://doi. org/10.7476/9788582930489

PINKER, Steven. As artes. In: PINKER, Steven. Tábula rasa: a negação contemporânea da natureza humana. Tradução Laura Teixeira Motta. São Paulo: Companhia das Letras, 2004. p. 541-566. https://doi.org/10.1590/s010237722005000300015

REIS, Carlos; LOPES, Ana Cristina M. Dicionário de teoria da narrativa. São Paulo: Ática, 1988. 327 p.

ROJO, Roxane (Org.). Escola conectada: os multiletramentos e as TICs. São Paulo: Parábola, 2013. 216 p.

SANTAELLA, Lucia. Três tipos de leitores: o contemplativo, o movente e o imersivo. In: SANTAELLA, Lucia. Navegar no ciberespaço: o perfil cognitivo do leitor imersivo. 2. ed. São Paulo: Paulus, 2007. p. 15-36.

SANTAELLA, Lucia. O ciberespaço e sua linguagem: a hipermídia. In: SANTAELLA, Lucia. Navegar no ciberespaço: o perfil cognitivo do leitor imersivo. 2. ed. São Paulo: Paulus, 2007. p.37-53.

SANTAELLA, Lucia. Comunicação ubíqua: repercussões na cultura e na educação. São Paulo: Paulus, 2013. 376p.

Recebido em: 27/10/2018.

Aprovado em: 05/03/2019.

Publicado em: 21/06/2019.

Autores:

Cleber Nelson Dalbosco

Doutor em letras pela Universidade de Passo Fundo. Professor da

Faculdade de Artes e Comunicação da UPF.

Orcid: https://orcid.org/0000-0002-5572-1417

E-mail: clebernelson@yahoo.com

TANia Mariza Kuchenbecker RösIng

Doutora e ex-integrante do curso de Pós-graduação em Letras da Universidade de Passo Fundo e da Universidade Regional Integrada do Alto Uruguai. Pesquisadora na área de leitura e formação do leitor. Idealizadora e coordenadora das Jornadas Literárias de Passo Fundo entre 1981 e 2015.

Orcid: https://orcid.org/0000-0002-9506-7296

E-mail: tmkrosing@gmail.com

Endereço: Av. Brasil Leste, 285 - São José

99052-900, Passo Fundo, RS, Brasil 